\title{
Analysis on Centrifugal Pump Performance in Single, Serial, and Parallel
}

\author{
Faisal Ansoria, Edi Widodo ${ }^{b}$ \\ a, bMechanical Engineering Department Universitas Muhammadiyah Sidoarjo \\ JI. Mojopahit No.666 B, Sidowayah, Celep, Kec. Sidoarjo, Kabupaten Sidoarjo, Jawa Timur 61271
}

\begin{abstract}
The pump is a tool to provide the mechanical energy to the liquid in the pump constant fluid density and large. In terms of mechanism, the pump is divided into three types, namely, rotary pumps, pump the shaft/piston and centrifugal pumps. The use of the pump are the most widely used either in the household or in the environment industry. In the centrifugal pumps, there are losses losses among other head losses. To find the head losses among other data needs head on the pump, the pump and the discharge flow rate of the pump. Head is defined as energy per unit weight of the fluid. The head of the unit $(H)$ meters or feet is fluid. In the pump, the head is measured by calculating the difference between the total pressure of the suction pipe and the pipe press, when measurement is done at the same height. For single full pump openings $0,00246 \mathrm{~m}^{3} \mid \mathrm{s}$, valve openings $3 / 4,0,00210$ and aperture of $1 / 20,00177 \mathrm{~m}^{3} \mid \mathrm{s}$ can be concluded the discharge of water at the pump the larger the opening of the valve the greater the discharge of its water. Moreover, vice versa, if the opening of the valve is getting smaller then the water debit is getting smaller. For full opening valves $3,11 \mathrm{~m} / \mathrm{s}$, for openings $3 / 42,65 \mathrm{~m} / \mathrm{s}$ and $1 / 22,23 \mathrm{~m} / \mathrm{s}$ open valve openings. For the flow, the larger valve opening the greater flow rate would be and, vice versa, the smaller valve opening the smaller flow rate would be. Single centrifugal pump full valve openings $0.409 \mathrm{~kg} / \mathrm{cm}^{2}$, the opening of the valve $3 / 4,0,209 \mathrm{~kg} / \mathrm{cm}^{2}$ and the opening of the valve $1 / 200,069$ $\mathrm{kg} / \mathrm{cm}^{2}$ resulted the smaller opening valve the smaller the head as well, and the greater valve opening, the bigger head in the can.
\end{abstract}

Keywords: pump system; valve; head

\section{INTRODUCTION}

Centrifugal pump is kinetic machine to transform mechanical to hydraulic energy through centrifugal activity, fluid pressure in the pump. Furthermore, even centrifugal pump is simple industrial equipment, yet it is mostly needed [1]. Making the pump meets the specification as it is planned; it mush have tests on its specification [2]. This pump is used for medium- to high-head with medium flow capacity. In its application, centrifugal pump is widely used for water filling process to kettle and household pump. Parts of centrifugal pump are stuffing box, packing, shaft, shaft sleeve, vane, casing, eye of impeller, impeller, casing wear ring and discharge nozzle.

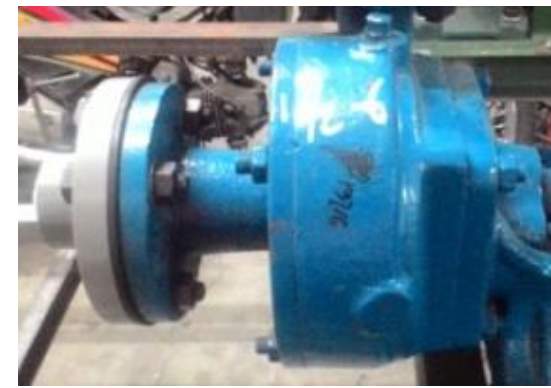

Figure 1. Longitudinal cross section of centrifugal pump

JEMMME | Journal of Energy, Mechanical, Material, and Manufacturing Engineering 


\subsection{Head}

Pump head is pump ability to transport fluid to different height or it is pump ability to transport fluid to different distance. Mechanically, pump head written as follow [3].Pressure head written in formulation as follow:

$$
\frac{P}{V}=\frac{P_{d}}{V}-\frac{P_{s}}{V}
$$

$$
\begin{aligned}
& \text { Where } \\
& h_{p}=\text { head press }(\mathrm{m}) \\
& p_{d}=\text { absolute outlet pressure }\left(\mathrm{N} / \mathrm{m}^{2}\right) \\
& p_{s}=\text { absolute inlet pressure }\left(\mathrm{N} / \mathrm{m}^{2}\right)
\end{aligned}
$$

\section{$1.2 \mathrm{~V}-$ Notch Weir}

In calculating debit on conduit, it uses v-notch weir. It is located on the notch with right triangle form. It measures outlet water flow with height parameter on v-notch weir.

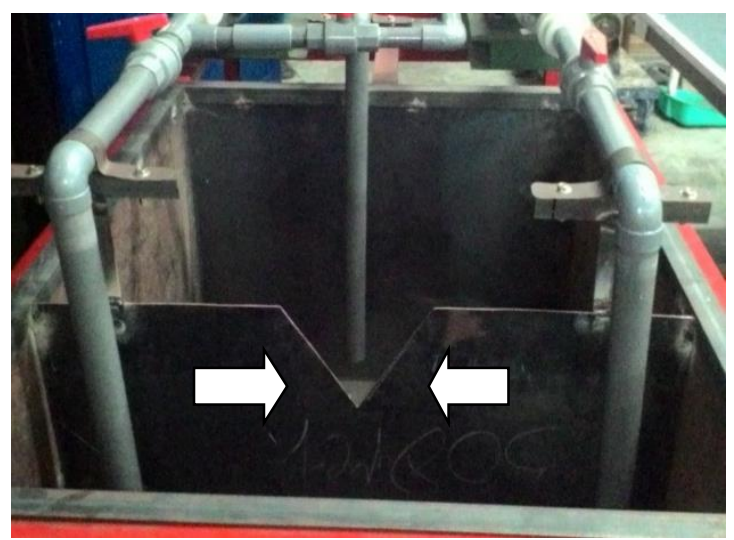

Figure 2. V-notch weir

Formulation used to calculate debit on v-notch weir is [4]:

$$
\begin{aligned}
& \text { V-notch formulation } \\
& Q=\frac{8}{15} \sqrt{2 \cdot g} \tan \frac{\theta}{2} H^{\frac{5}{2}}
\end{aligned}
$$

Where:

$Q$ = water debit

$\mathrm{g}=$ gravity velocity

$\theta=$ notch angle

$\mathrm{H}=$ water notch height on $\mathrm{v}$-notch weir

\subsection{Fluid Flow Speed}

Calculating fluid flow rate used fluid flow debit as follow [5]:

$$
Q=v \cdot A\left(\frac{m^{3}}{s}\right)
$$

Where:

$\mathrm{v}=$ fluid flow rate

$\mathrm{A}=$ plumbing cross-sectional area

Furthermore, to calculate the flow rate, the formulation is reversed:

$$
v=\frac{Q}{A}
$$

JEMMME | Journal of Energy, Mechanical, Material, and Manufacturing Engineering 
Where:

$V=$ fluid flow rate

$A=$ plumbing cross-sectional area

Cross-sectional area could be calculated by the following formulation:

$$
A=\pi(r)^{2}
$$

Where:

$A=$ cross-sectional area

$r=$ plumbing radius

\subsection{Reynolds number}

Reynolds number is ratio between inertia to viscosity that quantify the correlation of the both with a condition of current flow, this number is used to identify the kind of different flow; for example laminar and turbulence [6].

This Reynolds number explains fluid flow profile in pipe, namely:

- Laminar flow of $\mathrm{Re}<2300$

- Transition flow of $2300<\operatorname{Re}<4000$

- Turbulence flow of $\operatorname{Re}>4000$

Reynolds number to determine fluid flow within pipe is [6]:

Reynolds number $(R e)$ :

$$
R e=\frac{\rho \cdot V \cdot D}{v}
$$

Where:

$\rho=$ density $\left(\mathrm{kg} / \mathrm{m}^{3}\right)$ where water is 1000

$V=$ flow rate $(\mathrm{m} / \mathrm{s})$

$D=$ pipe diameter $(m)$

$v=$ kinematic viscosity $\left(\mathrm{m}^{2} / \mathrm{s}\right)$

\subsection{Head Losses}

To calculate friction loss between pipe wall and fluid flow without change on crosssectional area in pipe, it can use Darcy formulation that mathematically is written as follow [7]:

$$
H l=f \frac{L \cdot v^{2}}{D(2 g)}
$$

Where:

$$
\begin{array}{ll}
\mathrm{HI} & =\text { head losses } \\
\mathrm{f} & =\text { friction coefficient }\left(\frac{64}{R e}\right) \\
\mathrm{L} & =\text { pipe length }(\mathrm{m}) \\
\mathrm{V} & =\text { flow rate in pipe }\left(\frac{\mathrm{m}}{\mathrm{s}}\right) \\
\mathrm{D} & =\text { pipe diameter }(\mathrm{m}) \\
\mathrm{g} & =\text { gravitation acceleration }\left(\mathrm{m} / \mathrm{s}^{2}\right)
\end{array}
$$

\section{MeTHOD}

This chapter is going to explain method in relation to:

1. Planning and building simulation apparatus to test single, serial, and parallel pump. Planning testing instrument is preparing installation to obtain parallel and serial pump structure. The designed pump is as depicted in Figure 3. 


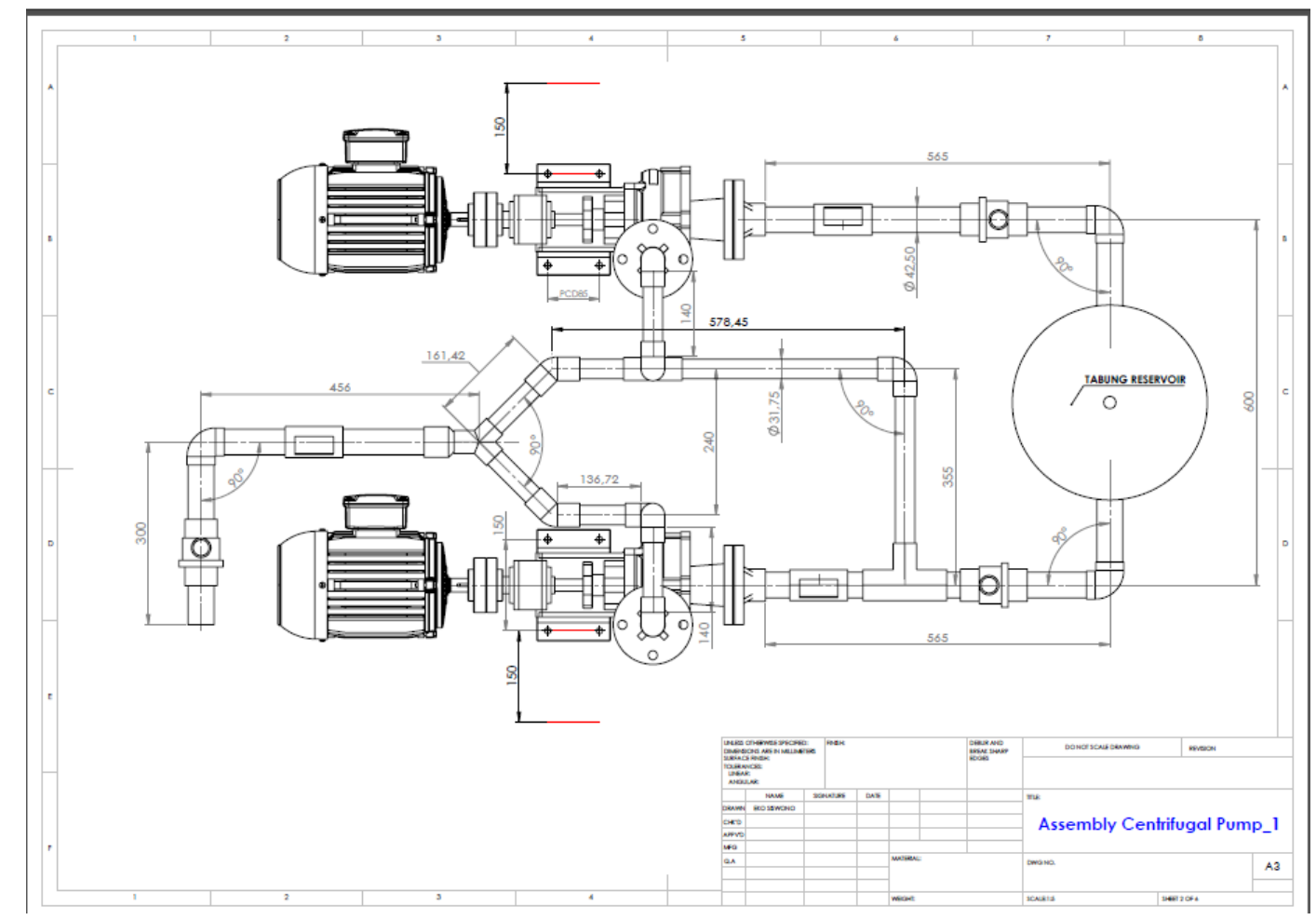

Figure 3. Structure of pump test equipment

Figure 3 shows installation scheme of pump testing to be built. Modification on serial and parallel is conducted by opening and closing valve installed.

2. Testing method.

Testing method is conducted by measuring debit, flow rate and head resulted by pump. Data on debit, flow rate, and pressure are utilized to obtain pump head.

3. Data analysis and performance graphics.

The results of testing data are processed to be derivation data including head loose, Reynolds number and flow rate

\section{ReSULt AND DisCUSSION}

3.1 Single Installation Centrifugal Pump

Result of analysis for testing single pump is as follow:

Table 1. Result of Single Installation Pump

\begin{tabular}{cccc}
\hline Valve aperture & $\begin{array}{c}\text { Water } \\
\text { Debit }\end{array}$ & $\begin{array}{c}\text { Fluid flow } \\
\text { rate }\end{array}$ & Head \\
\hline Full & 0,00246 & 3,11 & 0.409 \\
$1 / 2$ & 0,00210 & 2,65 & 0.209 \\
$3 / 4$ & 0,0007 & 2,23 & 0.069 \\
\hline
\end{tabular}




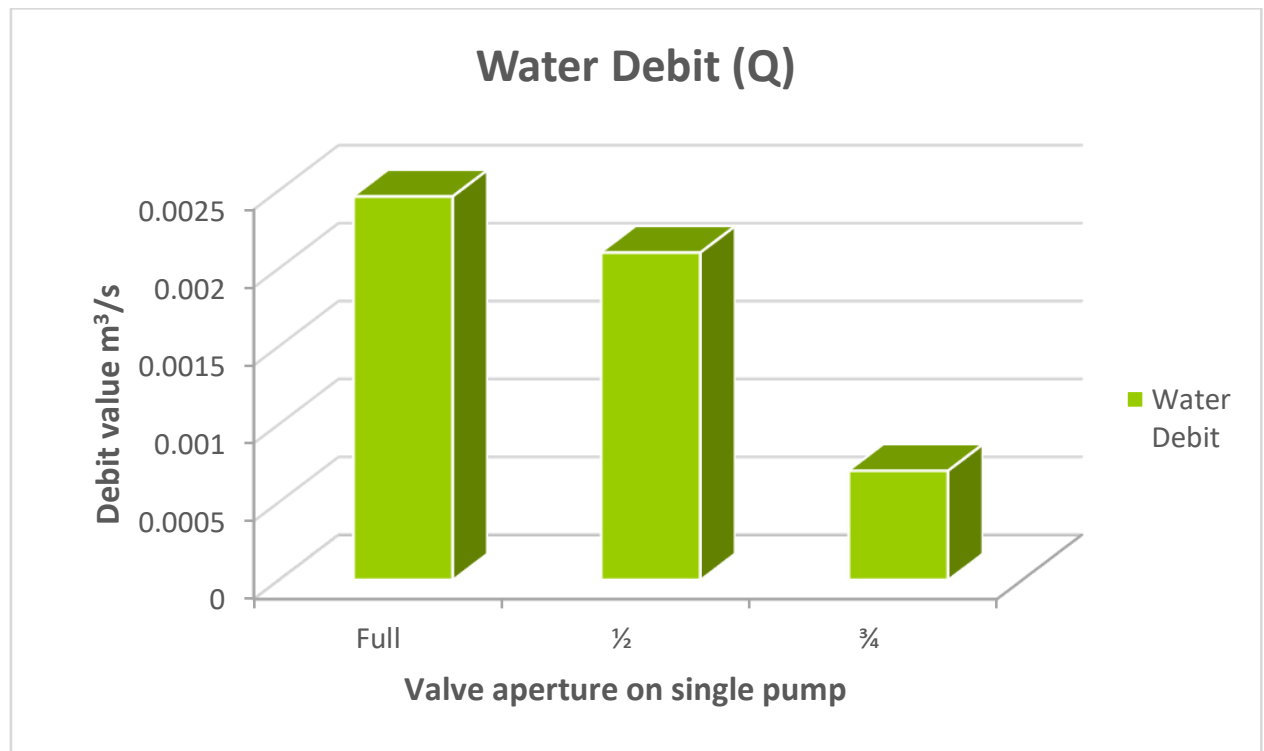

Graphic 1. Water debit on single installation pump

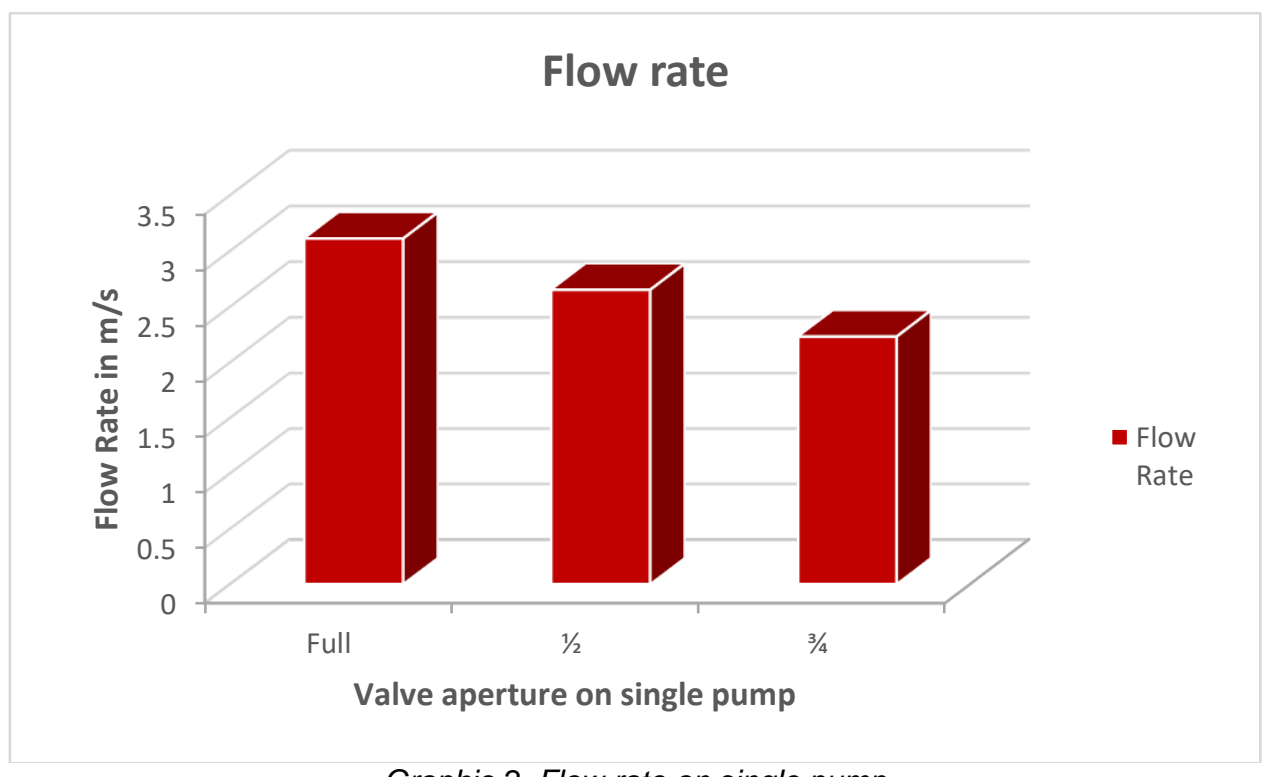

Graphic 2. Flow rate on single pump

Data on graphic 1 shows that full aperture has $0.00246 \mathrm{~m}^{3} \backslash \mathrm{s}$ of water debit, while $3 / 4$ valve aperture has $0.00210 \mathrm{~m}^{3} / \mathrm{s}$ of water debit and $1 / 2$ valve aperture has $0.00177 \mathrm{~m}^{3} \mathrm{~s}$ of water debit. This data shows that the wider valve aperture results higher water debit. In vice versa, the smaller valve aperture, the lower water debit.

In graphic 2, data on flow velocity shows that full valve aperture results $3,11 \mathrm{~m} / \mathrm{s}$ of flow velocity, while for $3 / 4$ valve aperture, it results $2,65 \mathrm{~m} / \mathrm{s}$ of flow velocity and $1 / 2$ valve aperture results $2,23 \mathrm{~m} / \mathrm{s}$ of flow velocity. Flow velocity increases with valve aperture. The higher valve aperture, the higher flow velocity and, vice versa, the smaller valve aperture, the smaller flow velocity. 


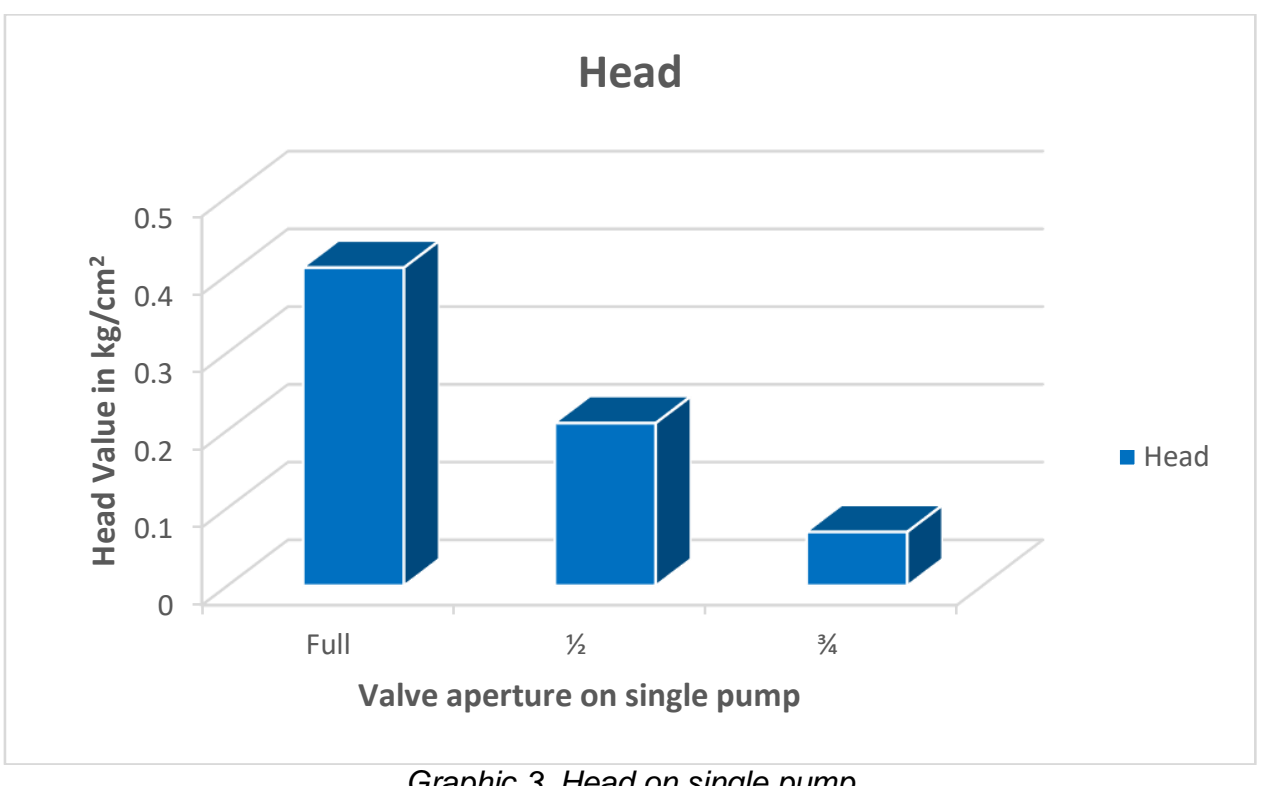

Graphic 3. Head on single pump

Based on graphic 3 head in full valve aperture is $0,409 \mathrm{~kg} / \mathrm{cm}^{2}$, while in $3 / 4$ valve aperture the head is $0,209 \mathrm{~kg} / \mathrm{cm}^{2}$ and in $1 / 2$ valve aperture the head is $0,069 \mathrm{~kg} / \mathrm{cm}^{2}$. It explains that the smaller valve aperture, the smaller the head and the wider valve aperture, the bigger head obatained.

\subsection{Serial Centrifugal Pump}

Resulf of centrifugal pump in serial shows in Table 2 below:

\begin{tabular}{cccccc} 
Aperture & $\begin{array}{c}\text { Suction } \\
\text { pressure }\end{array}$ & $\begin{array}{c}\text { Oable 2. Result of Pump in serial } \\
\text { pressure }\end{array}$ & Head & Debit & $\begin{array}{c}\text { Fluid flow } \\
\text { rate }\end{array}$ \\
\hline Full & 0.00003 & 0.18 & 0.17997 & 0.0021 & 2.26 \\
\hline
\end{tabular}

\subsection{Parallel Centrifugal Pump}

Result of centrifugal pump in parallel shows in Table 3 below:

Table 3. Resulf of Pump in parallel

\begin{tabular}{cccccc}
\hline Aperture & $\begin{array}{c}\text { Suction } \\
\text { pressure }\end{array}$ & $\begin{array}{c}\text { Outlet } \\
\text { pressure }\end{array}$ & Head & Debit & $\begin{array}{c}\text { Fluid flow } \\
\text { rate }\end{array}$ \\
\hline Full & 0.001 & 0.41 & 0.409 & 0.0068 & 8.58 \\
\hline
\end{tabular}

\subsection{Comparison Result of Centrifugal Pump}

Based on the data of full aperture on centrifugal pump, table 4 below shows the difference of centrifugal pump in single, parallel, and serial.

Table 4. Comparison on Centrifugal Pump

\begin{tabular}{ccccc}
\hline Aperture & Head & Debit & Flow rate & Installation \\
\hline \multirow{3}{*}{ Full } & 0.17997 & 0.0021 & 2.26 & Serial \\
& 0.409 & 0.0068 & 8.58 & Parallel \\
& 0.409 & 0.0025 & 3.11 & Single \\
\hline
\end{tabular}




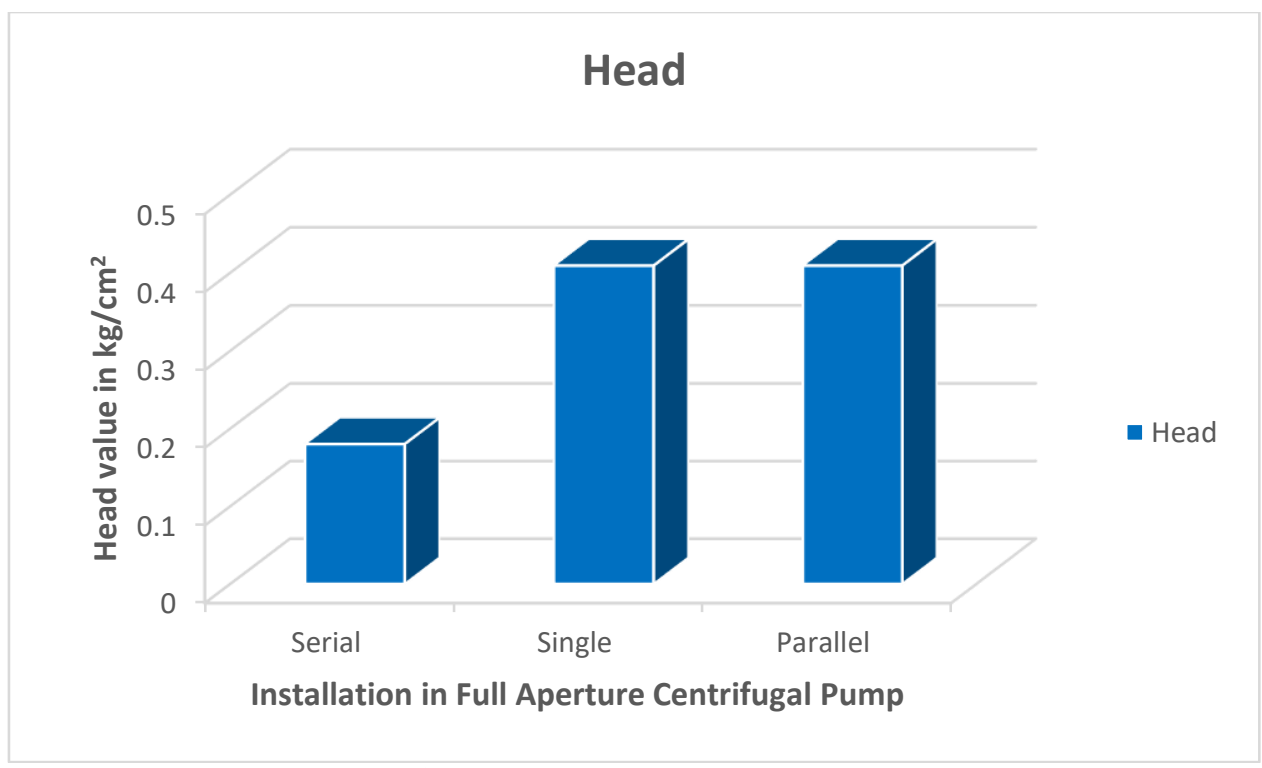

Graphic 4. Head in Full Aperture

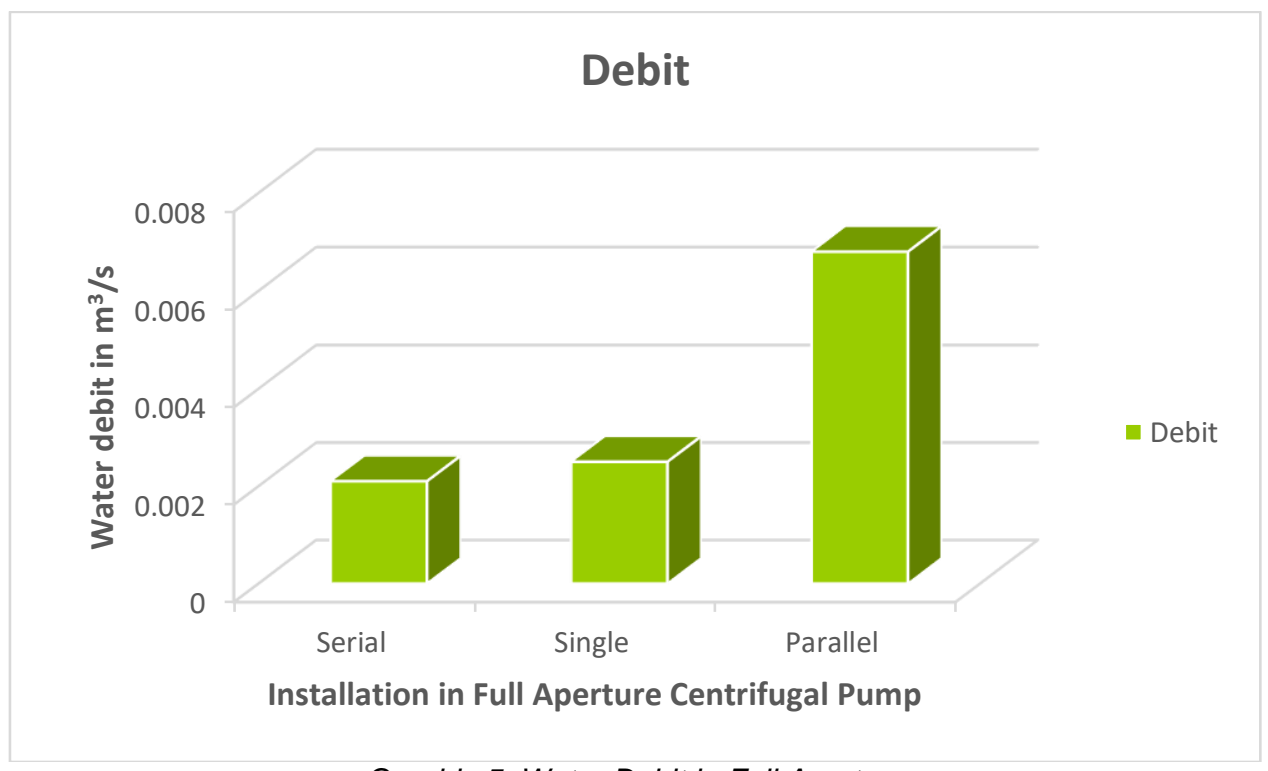

Graphic 5. Water Debit in Full Aperture

Graphic 4 shows head on parallel centrifugal pump is not achieving $0.2 \mathrm{~kg} / \mathrm{cm}^{2}$, while in serial and single centrifugal pump is the same in $0.4 \mathrm{~kg} / \mathrm{cm}^{2}$. It is as the result of piping in parallel installation only needs a pipe, while in serial, it needs 2 pipes.

In graphic 5 Debit on parallel centrifugal pump achieved $0.006 \mathrm{~cm}^{2} / \mathrm{s}$ while in serial and single centrifugal pump achieved almost the same in $0.002 \mathrm{~kg} / \mathrm{cm}^{2}$. It is because the pipe is only one, while in parallel, it uses 2 pipes.

As depicted in graphic 6 , flow velocity shows higher value in parallel centrifugal pump. It is $8.58 \mathrm{~m} / \mathrm{s}$. Moreover, single centrifugal pump results flow velocity value under parallel pump. It is $3.11 \mathrm{~m} / \mathrm{s}$ and the lowest is in serial centrifugal pump. It is $2.26 \mathrm{~m} / \mathrm{s}$. 


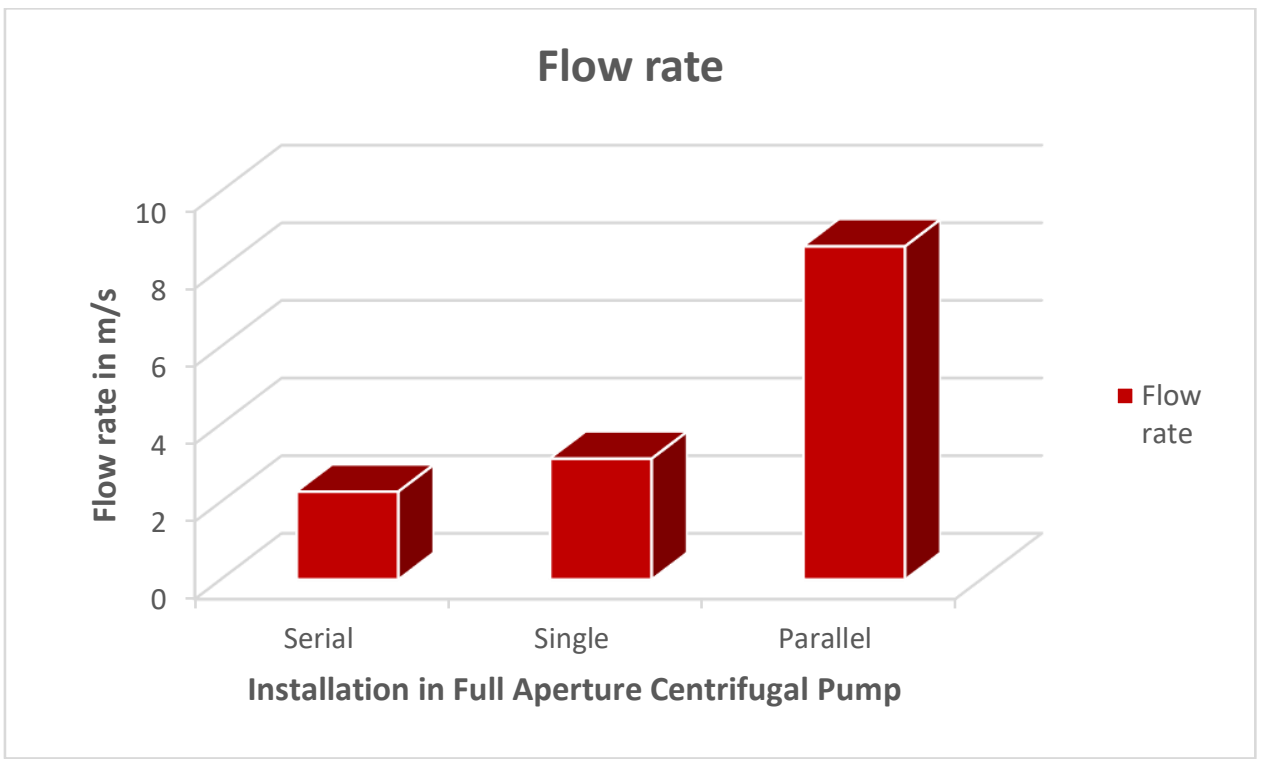

Graphic 6. Fluid Flow Velocity in Full Aperture

\section{Conclusion}

This research was conducted to find out the performance of centrifugal pump in single, serial, and parallel with full aperture. Result of this research is as explained below.

Research shows that head in parallel centrifugal pump is not achieving $0.2 \mathrm{~kg} / \mathrm{cm}^{2}$, while serial and single centrifugal pump resulted the same result in $0.4 \mathrm{~kg} / \mathrm{cm}^{2}$. It is because there is only one inlet pipe in serial and single pump, while parallel pump used 2 pipes.

Debit on parallel centrifugal pump reached $0.006 \mathrm{~cm}^{2} / \mathrm{s}$, while serial and single centrifugal pump had almost the same value in $0.002 \mathrm{~kg} / \mathrm{cm}^{2}$. It is because there is only one inlet pipe in serial and single pump, while parallel pump used 2 pipes.

Flow velocity value is bigger in parallel pump; it reaches $8.58 \mathrm{~m} / \mathrm{s}$, while single pump has lower value under parallel pump. It is $3.1 \mathrm{~m} / \mathrm{s}$. Moreover, the lowest is in serial pump. It is $2.26 \mathrm{~m} / \mathrm{s}$.

It is expected for further researcher to investigate further problem in this type of centrifugal pump.

\section{REFERENCES}

[1] F. Amirullah, Pengujian karakteristik pompa susunan paralel dengan spesifikasi berbeda Penguji. karakteristik Pompa Susunan Pararel Dengan Spesifikasi Berbeda, pp. 1-21, 2009.

[2] W. D. Putro, Pengujian Kinerja Pompa Sentrifugal Menggunakan Kontrol Inventer, vol. 13, no. 1, pp. 21-30, 2010.

[3] Nasirwan, Optimasi pengujian pompa seri dan paralel, vol. 5, no. 1, pp. 15-21, 2008.

[4] Helmizar, Studi Eksperimental Pengukuran Head Losses Mayor (Pipa PVC Diameter $3 / 4$ ) Dan Head Losses Minor (Belokan Knee $90^{\circ}$ Diameter 3/4) Pada Sistem Instalasi Pipa, Din. Tek. Mesin, vol. 1, no. 2, pp. 59-64, 2010.

[5] A. F. Silaen, Analisa Karakteristik Pompa Sentrifugal Rangkaian Single, Serie dan Pararel, vol. 3, pp. 1-40, 2011.

[6] waspodo, Analisa head loss sistem jaringan pipa pada sambungan pipa kombinasi diameter berbeda, pp. 1-12.

[7] R. Y. Pradhana and E. Widodo, Analisa Pengaruh Variasi Diameter Pipa Tekan Pvc Pada Pompa Aksial Untuk Kecepatan Gaya Dorong Air, vol. 2, no. 1, pp. 37-43, 2017. 